\title{
The retreat of a tidewater glacier: observations and model calculations on Hansbreen, Spitsbergen
}

\author{
Andreas Vieli, ${ }^{1,2 *}$ Jagek Jania, ${ }^{3}$ Lezek Kolondra ${ }^{3}$ \\ ${ }^{1}$ Institute for Atmospheric and Climate Science, Eidgenössische Technische Hochschule, Winterthurerstrasse 190, CH-8057 Zürich, Switzerland \\ E-mail: a.vieli@bristol.ac.uk \\ ${ }^{2}$ Section of Glaciology, Versuchsanstalt für Wasserbau, Hydrologie und Glaziologie, Eidgenössische Technische Hochschule, ETH-Zentrum, \\ CH-8092 Zürich, Switzerland \\ ${ }^{3}$ Department of Geomorphology, Faculty of Earth Sciences, University of Silesia, ul. Będzińska 60, PL-41-200 Sosnowiec, Poland
}

\begin{abstract}
Based on observations and model calculations, the retreat over the last two decades of Hansbreen, a tidewater glacier in southern Spitsbergen, Svalbard, is investigated. The observations of the calving-front position between 1982 and 1998 show an abrupt retreat in 1990, which is suggested to be related to a depression in the glacier bed. The observed seasonal variations of the front position are mainly due to variations of the calving rate. The observations of Hansbreen further indicate that during periods of slow front-position changes, melting at the water-line may play an important role in triggering the process of calving. The evolution of Hansbreen between 1982 and 1998 is simulated with a numerical model for the dynamics of tidewater glaciers. Using a flotation criterion for calving in which for each time-step the part of the glacier terminus which is below a critical height above buoyancy is removed, we are able to reproduce the observed rapid retreat of Hansbreen through the depression in the glacier bed. From the observations and model calculations, we conclude that the rapid retreat is mainly an effect of basal topography in the terminus region and not a direct response to a change in mass balance.
\end{abstract}

\section{INTRODUCTION}

The dynamical behaviour of tidewater glaciers, which are considered as grounded calving glaciers from which icebergs are discharged into the sea, is important with respect to their reaction to changes in climate. Length changes of tidewater glaciers are not only a result of a change in surface mass balance, they are additionally affected by calving at the terminus. Rapid retreats related to increased calving rates have been observed for several grounded calving glaciers (Van der Veen, 1996; Warren and Aniya, 1999). These rapid changes in front positions have been interpreted as less a direct response to changes in climate than a strong effect of the local basal topography near the terminus (Meier and Post, 1987; Warren, 1993; Naruse and Skvarca, 2000; Vieli and others, 2001).

In this paper, we focus on the dynamical behaviour of Hansbreen, a tidewater glacier, in southern Spitsbergen, Svalbard. With a length of $16 \mathrm{~km}$ and frontal flow velocities up to $150 \mathrm{~m} \mathrm{a}^{-1}$, Hansbreen is a relatively small, thin and slowly flowing tidewater glacier. Detailed front-position records between 1982 and 1998 exist, and the basal topography of the terminus region is known. Such an extensive dataset only exists for a few tidewater glaciers and provides the opportunity to investigate the effect of basal topography

\footnotetext{
* Present address: Bristol Glaciology Centre, School of Geographical Sciences, University of Bristol, Bristol BS8 1SS, England.
}

on the change of terminus position and to test a numerical model of the dynamics of tidewater glaciers. A special focus is provided on the observed rapid retreat of Hansbreen in 1990 through a depression in the glacier bed.

\section{Calving}

Calving is a very efficient ablation mechanism, and therefore is an important process for the dynamics of tidewater glaciers. Based on observations, empirical relations for the calving rate $u_{\mathrm{c}}$, which is defined as the difference between ice velocity at the terminus and the rate of change of the glacier length, have been determined. A linear relation between the calving rate and the water depth $d$ at the terminus was suggested for tidewater glaciers by Brown and others (1982). A linear relation has also been suggested for glaciers calving into fresh water, but for a given water depth the calving rate in fresh water is expected to be one order of magnitude below the value found in sea water (Funk and Röthlisberger, 1989).

Depressions in the basal topography are observed to be typical in the frontal region of tidewater glaciers. According to these empirical relations, the calving rate increases with a retreat of the terminus into deeper water, and a rapid unstable retreat through a depression in the glacier bed is therefore expected. This has been observed for several tidewater and fresh-water calving glaciers and suggests that these glaciers undergo cycles of slow advance and rapid retreat through depressions in the glacier bed (Meier and Post, 1987). For the case of rapidly changing glaciers the validity of these linear empirical relations has been questioned (Meier and Post, 1987; Van der Veen, 1996; Vieli and others, 2001). 
In general, for temperate tidewater glaciers no floating tongues occur. During the rapid retreat of Columbia Glacier, Alaska, U.S.A., in the 1980s, the terminus appeared to retreat to the position where it did approach flotation thickness (Meier and Post, 1987). On the basis of these observations, Van der Veen (1996) suggested an alternative treatment of calving to the empirical relations for the calving rate discussed above. In this flotation model the part of the terminus that is too close to flotation calves off due to buoyancy forces and weakening of the ice by bottom crevasses (Van der Veen, 1998). The glacier terminus retreats to the position where the ice thickness $h$ exceeds the flotation height by an amount of $h_{\mathrm{o}}$ (Van der Veen, 1996). For Columbia Glacier a value of $h_{\mathrm{o}}=$ $50 \mathrm{~m}$ was found. This flotation model is found to be consistent with the observed rapid retreat of grounded calving glaciers in Patagonia, for which a similar critical height above buoyancy was derived (Venteris, 1999).

Using a similar flotation criterion for calving in a numerical model for the dynamics of tidewater glaciers, the length change through a depression in the glacier bed is discussed in Vieli and others (2001). Their model calculations confirm that rapid changes of tidewater glaciers are mostly an effect of bed topography, and to a minor degree a direct reaction to mass-balance changes. Furthermore, they show that rapid retreats take place in regions where the bed slopes up in the flow direction and that for these periods of rapid changes calving rates do not follow the empirical relations.

\section{Melting at the calving front}

In most studies concerning the calving process, subaqueous melting at the terminus is neglected, because the total mass loss by melting at the calving front is found to be small compared to the mass loss by calving (Powell, 1988). Based on a study by Neshyba and Josberger (1980), Jania (1988) estimated for Hansbreen a total mass loss by submarine melting that was $<10 \%$ of the loss by calving. Hanson and Hooke (2000) pointed out that the energy in the far-field water is often sufficient to melt ice at rates in the range of observed calving rates, but the problem is to bring this water to the calving front. From studies on the deterioration of icebergs, melting concentrated to the water-line is known to be one to two orders of magnitude higher than below the surface (White and others, 1980; El-Tahan and others, 1987) due to wave erosion. The resulting undercut notch at the water-line of icebergs leads to calving of overhanging ice slabs above. Although the total mass loss by melting is still small, melting at the water-line plays an important role by triggering the process of calving. For icebergs, $80 \%$ of the deterioration rate is found to be due to melt-induced calving, which includes melting at the water-line and the resulting calving of the overhanging slabs (El-Tahan and others, 1987). For icebergs in the open sea, melt rates at the water-line of about $2 \mathrm{~m} \mathrm{~d}^{-1}$ are common (Robe and others, 1977), and strong seasonal variations occur due to changes of sea temperature. During wintertime, sea-ice cover additionally prevents wave erosion at the water-line.

On several slowly flowing grounded calving glaciers, a permanent notch melted out at the water-line, and the resulting breaking-off of thin ice lamellae above it is also observed (Warren, 1999; Vieli and others, 2001) and has been described in detail for Maud Glacier, New Zealand, by Kirkbride and Warren (1997). Due to differences between open ocean and fjords in sea surface conditions, salinity and water flow, melt rates at the water-line are expected to be smaller for tidewater glaciers than for icebergs, but the seasonal pattern may be very similar.

\section{Basal sliding}

Basal sliding is an important process for controlling the dynamics of tidewater glaciers. Increasing basal sliding velocities are expected for a decreasing effective pressure $p_{\mathrm{e}}$ at the bed (Bindschadler, 1983; Boulton and Hindmarsh, 1987), which is defined as the ice-overburden minus the basal water pressure. Within a tidewater glacier the basal water pressure amounts to at least the water pressure that corresponds to sea level and therefore comes close to the ice-overburden pressure near the terminus. The generally high water pressure may partly explain the observed high sliding velocities in the terminus region observed for tidewater glaciers (Meier and Post, 1987). For Hansbreen the observed velocity increase towards the calving front could be explained by using a water-pressure-dependent sliding law (Vieli and others, 2000).

\section{HANSBREEN: GEOGRAPHICAL SETTING AND OBSERVATIONS}

Hansbreen is a tidewater glacier situated at Hornsund in southern Spitsbergen (Fig. la). It is about $16 \mathrm{~km}$ long and covers an area of $57 \mathrm{~km}^{2}$. The glacier is grounded and ends with a $1.3 \mathrm{~km}$ wide calving front. Glaciological investigations were initiated during the Third International Geophysical Year by Kosiba (1960), continued by Baranowski (1977) and since 1982 extended by Jania $(1988,1994)$. Surface topography is known for the years 1936 and 1990 from aerial photogrammetry. Bed topography was investigated by radio-echo soundings (Glazovskiy and others, 1992; Moore and others, 1999) and depth soundings of the fjord in front of the glacier (Giżejewski, 1997). Annual mass-balance measurements are available since 1989, with a gap in 1996 and 1997 (Haeberli and others, 1996; Jania and Kaczmarska, 1997). The mean average net balance (without calving) over the period 1991-95 is $-0.21 \mathrm{mw}$. e. $\mathrm{a}^{-1}$, and the mean equilibrium-line altitude (ELA) is $338 \mathrm{~m}$ a.s.l. The mean net balance between 1936 and 1990 estimated from the volume change of Hansbreen by comparing topographic maps from these two years is of the same magnitude (Jania, 1994). The present accumulation-area ratio (AAR) for Hansbreen is about 0.38, and the ratio of calving to the surface melt is about 0.22 . Glacier front positions and surface flow velocities have been measured by terrestrial photogrammetry in the frontal part of the glacier since 1982 (Jania and Kolondra, 1982) and in a longitudinal profile in 1998 by terrestrial survey (Vieli and others, 2000) and in 1999 by global positioning system (GPS) (Fig. la). First front-position measurements date from 1918 and 1936. Since 1957 the calving front of Hansbreen has been monitored more frequently using the method of terrestrial photogrammetry. From 1936 until 1982, Hansbreen retreated by about $1.4 \mathrm{~km}$, corresponding to a mean retreat rate of $22.5 \mathrm{~m} \mathrm{a}^{-1}$. The retreat was interrupted by a few short periods of advance in 1957-59 and 1973-77 (Jania and Kaczmarska, 1997).

\section{Frontal positions, 1982-98}

Since 1982 the position of the calving front of Hansbreen has been monitored systematically by means of terrestrial 


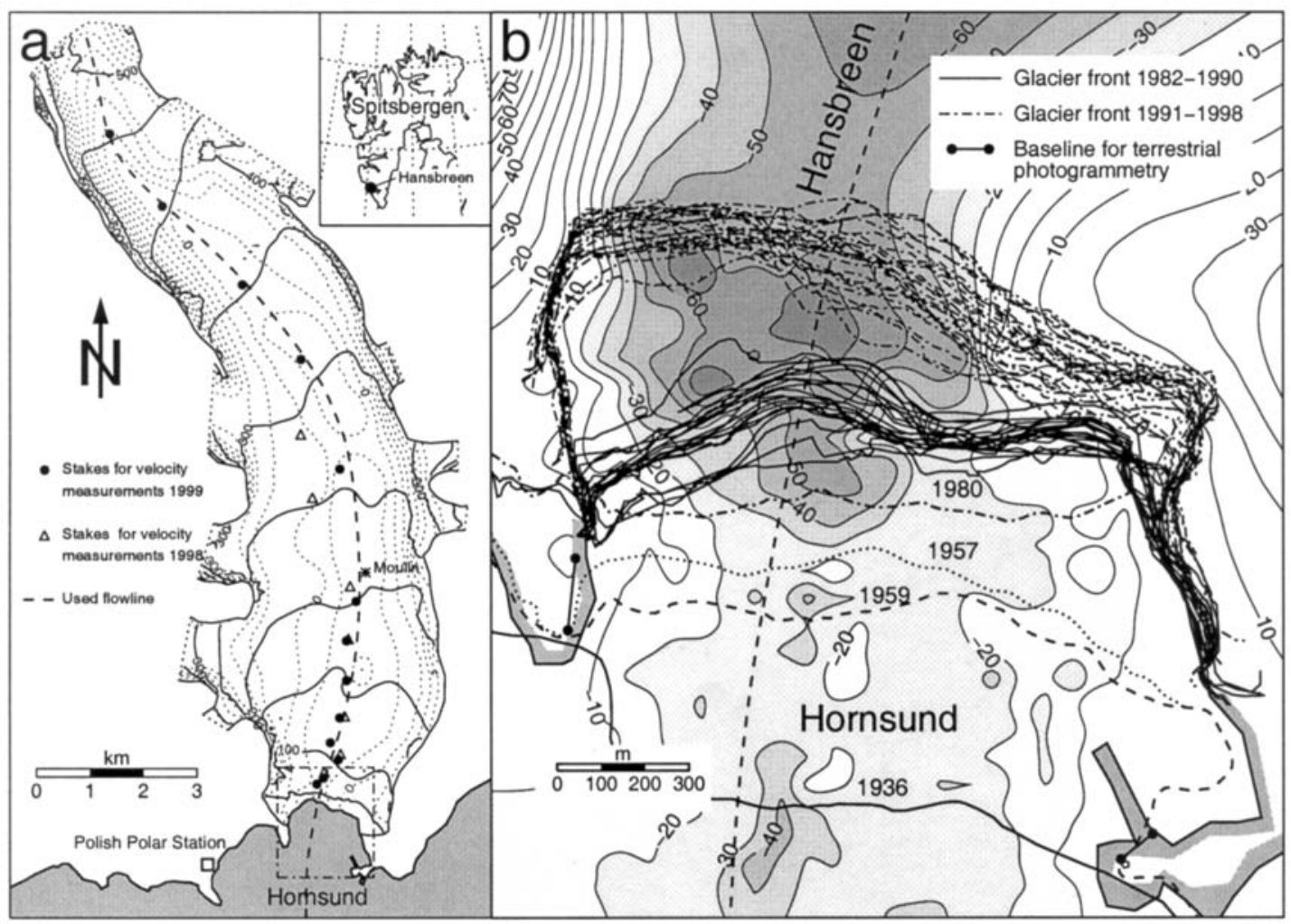

Fig. 1. (a) Map of Hansbreen showing glacier surface topography (solid contour lines) and bed topography (dotted contour lines). The contour intervals are $50 \mathrm{~m}$. The dashed line indicates the flowline used, and the star the location of a glacier moulin, in which water pressure was monitored. The locations of the stakes used for the velocity measurements are shown with triangles for 1998 and black dots for 1999. The dashed-dotted rectangular frame indicates the zoomed area shown in (b). (b) Map of the frontal part of Hansbreen showing all observed terminus positions between 1982 and 1998 . The thick solid lines show the front lines before the abrupt retreat in 1991, and the dashed-dotted lines the front lines after it. Three additional terminus positions before 1982 are shown and labelled with the corresponding year. Basal topography is shown as grey shades and contour lines with a contour interval of $10 \mathrm{~m}$. The dashed line indicates the flowline used for the model calculations.

photogrammetry (Jania and Kolondra, 1982). From three different baselines, repeated stereoscopic photographs were taken (Fig. 1b), at least once a year, usually during summer. For the years 1986 and 1991/92, nearly complete annual cycles were recorded with a temporal resolution of about 2 months. There are no observations in winter between November and February because of darkness during polar night. The observed front positions of Hansbreen between 1982 and 1998 are shown in Figure 1b. The glacier length averaged over a $200 \mathrm{~m}$ wide stripe along the flowline for the same period is shown in Figure 2. A general slow retreat of Hansbreen since 1982 as well as seasonal variations of the terminus position are observed.

From 1982 until 1990 the terminus continuously retreated at a rate of about $28 \mathrm{~m} \mathrm{a}^{-1}$. Between 1990 and 1991, the frontposition record shows a jump in the retreat of about $280 \mathrm{~m}$ (Fig. 2). Plotting all observed front lines between 1982 and 1998 on a map of Hansbreen (Fig. 1b) shows that the front positions before and after this abrupt change are clearly separated from each other. This sudden retreat is more pronounced in the western part, where the water is deeper than in the eastern part. After 1991, the terminus was more or less stable, with a slight advancing tendency.

The terminus positions of Hansbreen additionally show seasonal variations, with an advance during winter and a retreat during summer (Fig. 2). During the well-documented years 1986 and 1991/92 (Fig. 2b and c) the terminus advances from October until the beginning of June with a rate of 0.33 and $0.55 \mathrm{~m} \mathrm{~d}^{-1}$, respectively. The retreat phase starts in June and continues until October, with a retreat rate of $1.04 \mathrm{~m} \mathrm{~d}^{-1}$ for summer 1986. For other years with less temporal resolution of the front-position measurements, the estimated summer retreat is generally smaller than the 1986 value (Table 1). The inferred summer retreat and winter advance rates are consistent with results of Jania (1988).

\section{Observations related to calving}

In winter, especially during periods with sea ice, calving activity is close to zero (Jania, 1988; Jania and Kaczmarska, 1997). During periods with open water, the calving front is observed to be undercut at the water-line, due to melting and wave erosion (Fig. 3). During the summers of 1998 and 1999, at least, this notch at the water-line persisted through-

Table. 1. Estimated maximum summer retreat rates and winter advance rates from observed front-position changes

\begin{tabular}{ccc} 
Year & $\begin{array}{c}\text { Winteradvance rate } \\
\mathrm{md}^{-1}\end{array}$ & $\begin{array}{c}\text { Summer retreat rate } \\
\mathrm{m} \mathrm{d}^{-1}\end{array}$ \\
\hline $1983^{*}$ & 0.29 & -0.99 \\
$1984^{*}$ & 0.28 & -0.93 \\
1986 & 0.33 & -1.04 \\
1988 & - & -0.54 \\
1991 & 0.55 & - \\
1993 & - & -0.95 \\
1995 & 0.42 & -0.32 \\
& & \\
\hline
\end{tabular}

\footnotetext{
* Data from Jania (1988).
} 

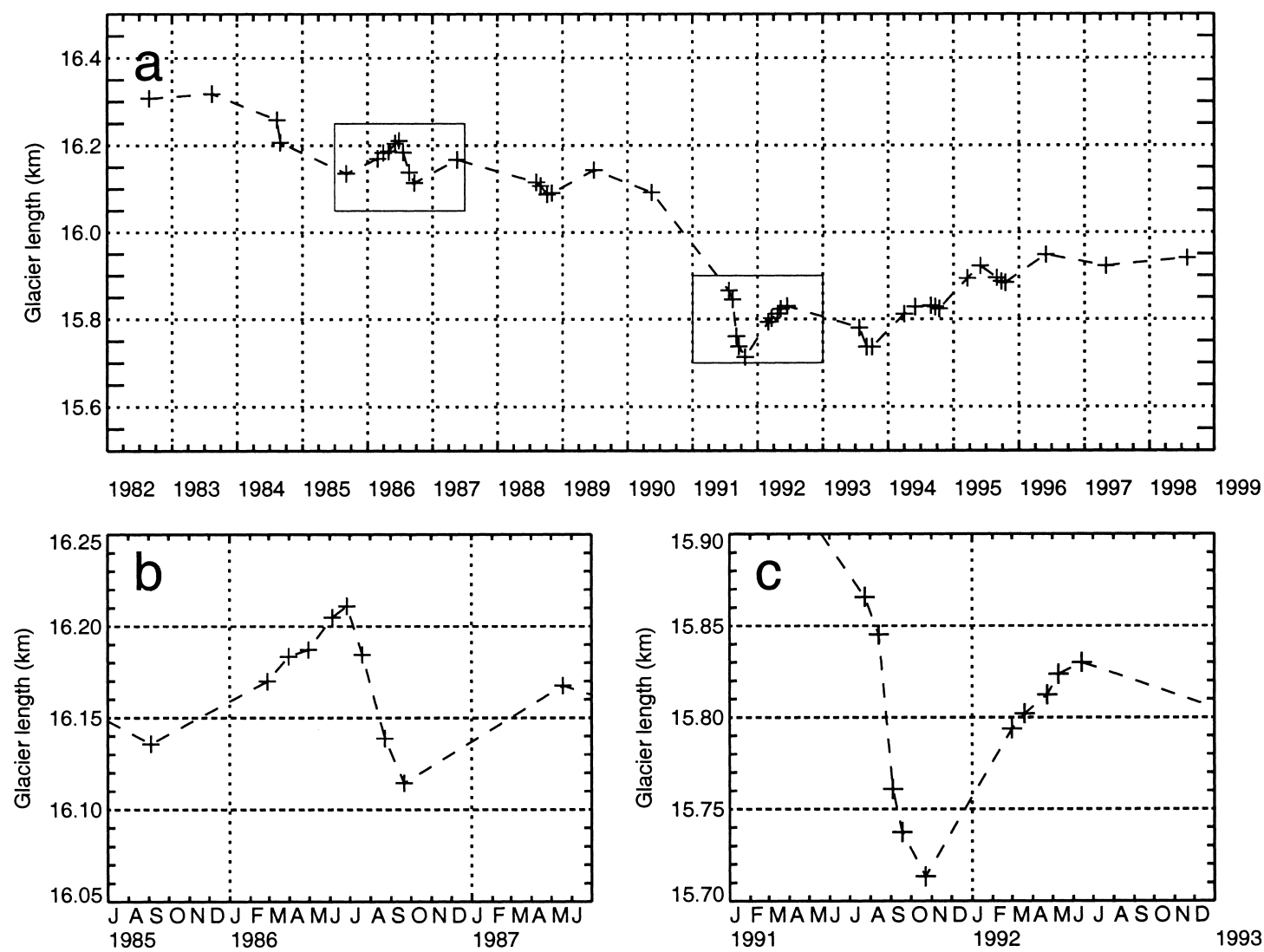

Fig. 2. (a) Observed glacier front positions averaged over a $200 \mathrm{~m}$ wide stripe along the flowline for the period 1982-98. (b,c) The seasonal cycles of the years $1986(b)$ and 1991/92 (c).

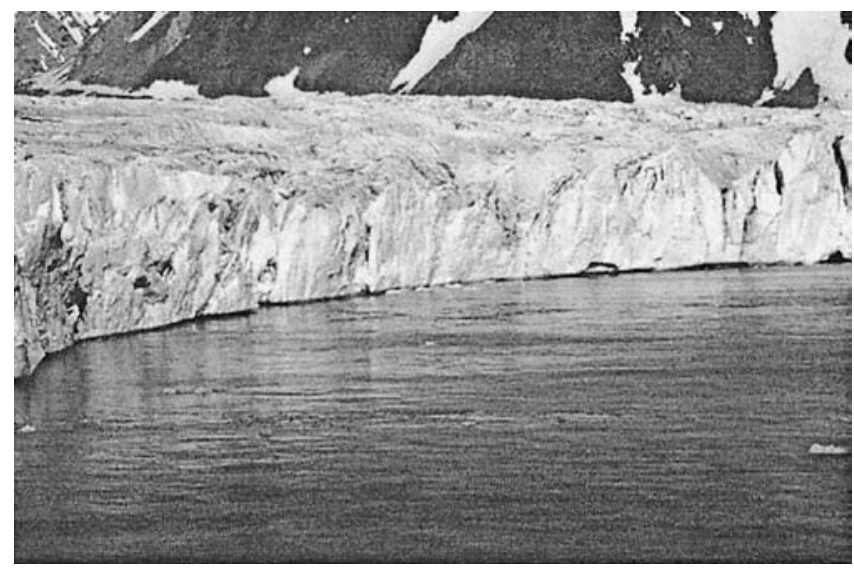

Fig. 3. View of the calving front of Hansbreen. The notch melted out at the water-line shown on the photograph extends all along the calving face and persisted throughout the melting season. The height of the calving face is $18-30 \mathrm{~m}$, and the water depth 40-70 $\mathrm{m}$. The photograph was taken at low tide in fuly 1999.

out the investigation period. The overhanging ice above the notch broke off in thin lamellae and fractured into many small-order $(\mathrm{m})$ pieces of ice. This is the most common process of calving observed at Hansbreen and has been described in Jania (1988). The notch at the water-line was also visible on the photographs taken between 1982 and 1998 for the frontposition survey of Hansbreen by photogrammetry and has also been observed at several other calving glaciers of similar size in the Hornsund region. Occasionally, single large icebergs in the order of $20 \mathrm{~m}$ rising to the sea surface were observed, indicating subaqueous calving. They surfaced at a distance from the calving face of about $50 \mathrm{~m}$ and are one to two orders of magnitude larger than the largest pieces from calving above the water-line. Sediment layers on the observed icebergs indicate their glacier-bed origin.

During hydrological investigations in 1981/82, seasonal variation of the sea surface temperature and the sea-ice cover at Hornsund was measured (Swerpel, 1982; Moskal, 1987). In summer, sea surface temperatures were about $2^{\circ} \mathrm{C}$, whereas from October to June the surface temperatures were below freezing and the fjord was mostly covered by sea ice (Fig. 4). In the 1997/98 season the Hornsund region was found to be covered by sea ice from the end of November until the beginning of June (U.S. National Ice Center, Washington, DG, http://www.natice.noaa.gov). Nevertheless, longer periods with ice-free conditions near the Hansbreen front were observed during winter.

\section{Flow velocities}

Annual ice-flow velocities at the terminus found by terrestrial photogrammetry and survey are in the range $0.30-$ $0.45 \mathrm{~m} \mathrm{~d}^{-1}$ (Jania, 1988; Vieli and others, 2000). Temporal variations of flow velocities have been observed by Jania (1988) and were investigated in detail in summer 1998 (Vieli and others, 2000) and summer 1999. On a monthly or seasonal scale, the available observations show that there are almost no changes in velocity and the ice speed is found to be rather constant through the year. On a daily or weekly basis, clear temporal variations in ice speed are visible. Sporadic speed-up events are observed during the melting season, with an increase in surface flow velocities up to a factor of five and a typical duration of 1-2 days (Vieli and others, 2000). These speed-up events are related to enhanced basal water pressure during periods of enhanced water input to the glacier due to rainfall or enhanced surface melt. 

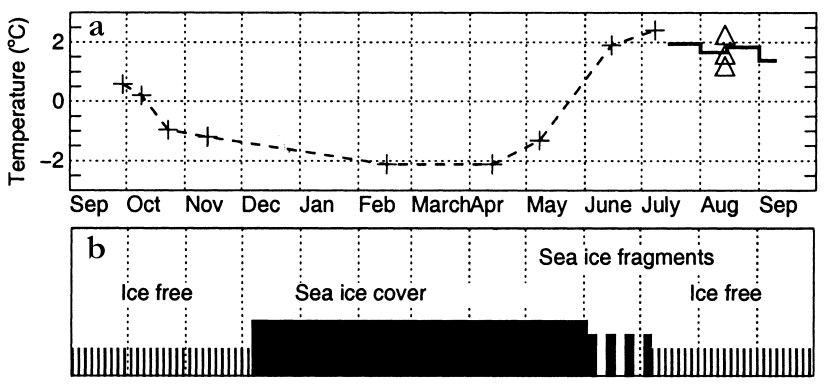

Fig. 4. (a) Sea surface temperatures of Hornsund in the vicinity of Hansbreen, shown for the year 1981/82 (crosses with dashed line; Moskal, 1987) and summer 1975 (triangles and thick solid line; Swerpel, 1982). (b) Observed seasonal pattern of sea ice covering Hornsund in the vicinity of the calving front of Hansbreen for the year 1981/82 (Moskal, 1987).

Because of the short duration of these events, they have only a minor effect on the mean annual and seasonal velocities.

Surface velocities along the flowline were measured in the summers of 1998 (Vieli and others, 2000) and 1999 and are shown in Figure 5. The velocities during a short period immediately after a speed-up event (termed slow-flow 98 and slow-flow 99) were found to be slightly lower than the mean annual values. Before a speed-up event in 1999, the velocities were nearly constant for 2 weeks, with values very close to the mean annual velocities, and are assumed to be representative for the mean annual flow (Fig. 5b). This period is termed mean-flow 99.

The measured velocity variations are related to variations of basal water pressure. The water pressure in a glacier moulin, located $4.5 \mathrm{~km}$ upstream of the terminus (Fig. la), was recorded in summer 1999, simultaneously with the velocity measurements (Fig. 5a). For the slow-flow 99 period, a water level of about $50 \mathrm{~m}$ a.s.l. was observed, and for the mean-flow 99 period it was $120 \mathrm{~m}$ a.s.l.

\section{INTERPRETATION AND DISGUSSION OF OBSERVATIONS}

\section{Long-term changes, 1982-98}

The observed retreat from 1982 to 1998 follows the observed general retreat and surface lowering since 1936, except for the jump in the terminus retreat of about $280 \mathrm{~m}$ from 1990 to 1991 (Fig. 2). Before and after this abrupt retreat, the frontal position underwent only small changes in the range of seasonal variations. The rapid retreat of 1990/91 can be explained by a temporary strong increase in the calving rate.

Climatic and mass-balance records do not indicate any abrupt change for this time period outside the range of the annual variability; however, the length-change signal is strong and short. Therefore, the rapid retreat cannot be a direct and immediate result of a sudden mass-balance change. A depression in the basal topography with a maximum depth of about $78 \mathrm{~m}$ below sea level is located between the glacier front lines before and after the abrupt retreat of 1990/91 (Fig. 1b). This suggests that the retreat was affected by the basal topography. Earlier observations and numerical model experiments showed that such accelerated retreats are likely to occur through depressions in the bed of a glacier (Meier and Post, 1987; Vieli and others, 2001). With continuing thinning and retreat of the glacier, due to a negative mass balance, the flotation level is approached in the region

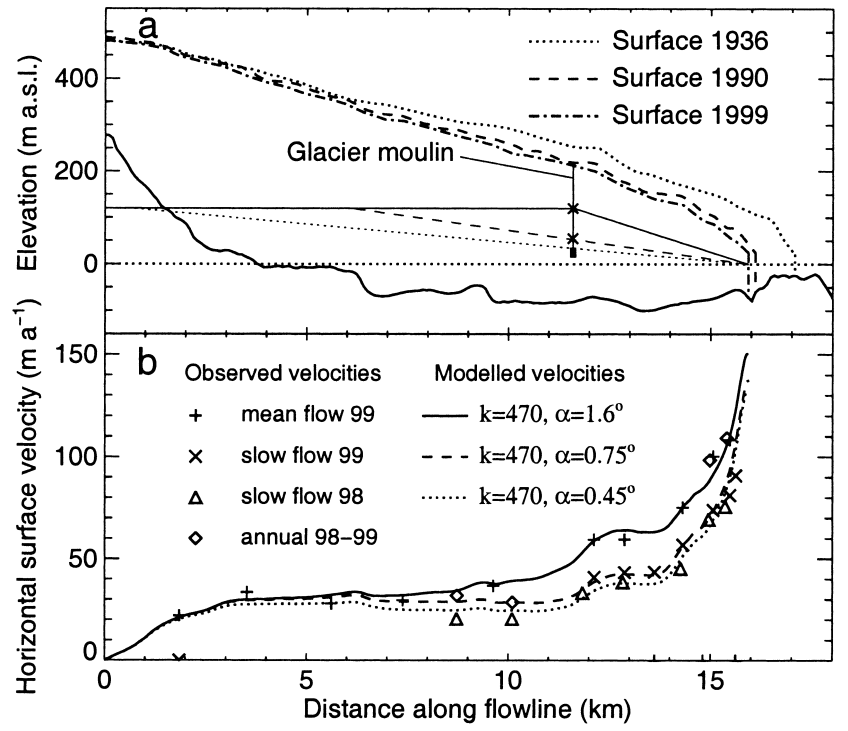

Fig. 5. (a) Profile along the flowline of Hansbreen with glacier bed (solid line) and surface topography for the years 1936, 1990 and 1999. The lines within the glacier show the assumed englacial water levels for the model calculations following later. The two crosses show observed englacial water levels measured in a glacier moulin during the mean-flow 99 (upper) and the slow-flow 99 period (lower). (b) The symbols indicate measured surface flow velocities for the three different periods. The lines show the velocities from the model calculations following later. The solid line represents the best fit of the modelled velocities to the observed mean-flow 99 velocities (crosses). The sliding parameter $k$ is in $m a^{-1}$.

of the depression in the bed, and increased calving due to buoyancy forces occurs. The decreasing effective pressure there leads to enhanced sliding, longitudinal stretching and bottom crevassing and may additionally weaken the ice (Van der Veen, 1996, 1998). Thus the observations from Hansbreen suggest that the abrupt retreat is mostly an effect of the bed topography at and behind the terminus, and the high calving rates are expected to be a result of the glacier dynamics in the region of a depression in the glacier bed.

The slight readvance observed between 1993 and 1996 (Fig. 2) may be a consequence of reduced summer calving rates due to changes in climatic conditions. The observations clearly show that summer retreat rates were significantly reduced in 1994 and 1995 (Fig. 2). The readvance may also be a dynamical reaction to the abrupt removal of the terminus part in 1990/91. The reason for the readvance cannot be determined unambiguously because it was not observed whether the glacier was thinning or thickening near the terminus after the rapid retreat in 1991.

\section{Seasonal variations}

The seasonal variation of the front position is determined by the seasonal change of the calving rate and the flow velocity at the glacier terminus. The observed speed-up events showed that, on a time-scale of days, strong velocity variations occur on Hansbreen during the melt season. On time-scales of months or seasons, these events do not significantly change the ice flow. Thus seasonal variations of the frontal velocities are small compared to the fluctuations of terminus position, and seasonal changes of the front position are mainly due to a seasonal variation of the calving rate. A calving rate close to zero during winter implies that the advance rate matches the 
flow velocity at the terminus. The observed values for the winter advance rate of the front position in 1986 and 1991/92 are in the range of frontal ice-flow velocities of $0.30-0.45 \mathrm{~m} \mathrm{~d}^{-1}$ directly measured by terrestrial photogrammetry and survey (Jania, 1988; Vieli and others, 2000).

Assuming constant flow velocities over the year, a seasonal pattern of the calving rate can be estimated from the observed changes in front positions. The inferred annual calving cycle yields no calving from October to the beginning of June ( $\sim 8$ months) and high calving rates between June and October ( $\sim 4$ months). This step function is a first approximation to the annual calving cycle. In reality, the switch in the calving rate between seasons is expected to be more gradual.

The summer calving rate can be estimated from the observed summer retreat rate $\mathrm{d} L / \mathrm{d} t$ and the frontal ice velocity $u_{\mathrm{i}}$, which is assumed to be equal to the winter advance rate. For the best-documented year, 1986, a summer calving rate of $u_{\mathrm{c}}=u_{\mathrm{i}}-\mathrm{d} L / \mathrm{d} t=0.33 \mathrm{~m} \mathrm{~d}^{-1}+1.04 \mathrm{~m} \mathrm{~d}^{-1}$ $=1.37 \mathrm{~m} \mathrm{~d}^{-1}$ is obtained, which corresponds to a mean annual calving rate of $164 \mathrm{~m} \mathrm{a}^{-1}$. Rough estimations for the other years give values for the summer calving rate which are similar to or below that in 1986 (Table 1). For the year $1991 / 92$ it is difficult to see the annual signal of the frontal position because of the rapid retreat. The main calving period corresponds to the period of surface melting and highest sea-water temperatures in the fjord (Fig. 4).

The observed notch at the calving front of Hansbreen suggests that melting at the water-line may play an important role in the calving process by inducing the break-off of the ice slabs above the notch as observed for icebergs (ElTahan and others, 1987). The melt rate at the water-line is zero when the temperature is $<0^{\circ} \mathrm{C}$ or when wave activity is suppressed by sea-ice cover in the vicinity of the calving face. From the observed seasonal pattern of the sea surface temperatures and the duration of sea-ice cover (Fig. 4), we expect a melt rate at the water-line which is close to zero from the beginning of October until June and is highest in late summer. This seasonal pattern is very similar to the one found for the calving rate and indicates a link between melting at the water-line and calving. If melting at the water-line produces calving, the melt rate should be in the range of the observed calving rates. Between 1982 and 1998, summer calving rates up to $1.37 \mathrm{~m} \mathrm{~d}^{-1}$ occurred. Using a relation derived from studies on iceberg deterioration (ElTahan and others, 1987), a rough estimation of the summer melt rate at the water-line for Hansbreen is $1 \mathrm{md}^{-1}$, assuming a surface water temperature of $2^{\circ} \mathrm{C}$, a wave height of $0.1 \mathrm{~m}$ and a wave period of $1.5 \mathrm{~s}$. This melt rate is in the range of the observed summer calving rates but may be an overestimate, because the relation was derived for icebergs in the open sea. However, for Hansbreen the direct observations of calving and the permanent and persistent notch at the water-line every summer show that melting at the water-line has to be taken into account at least as a triggering mechanism for calving and as a possible explanation for the observed seasonal fluctuation of the front position during periods of slow retreat.

The calving of ice lamellae above the water-line should lead to a submarine ice foot. The large icebergs that occasionally rise to the sea surface in front of the calving front of Hansbreen indicate the development of an ice foot below the surface, which might be due to enhanced submarine melting near the surface (Hunter and Powell, 1998). Icebergs detach from the ice foot when buoyancy exceeds a critical stress for failure.

\section{Calving-rate/water-depth relation}

For the year 1986 the annual calving rate is estimated to be $164 \mathrm{~m} \mathrm{a}^{-1}$. For the period 1982-90 a mean calving rate of $150-190 \mathrm{~m} \mathrm{a}^{-1}$ is found, assuming flow velocities according to observations of $110-164 \mathrm{~m} \mathrm{a}^{-1}$. The water depth at the terminus in the middle part of the glacier is about $50 \mathrm{~m}$, and averaged over the glacier width it is $30 \mathrm{~m}$. These observed calving rates are far below the value expected from the calving-rate to water-depth relationship suggested for Alaskan tidewater glaciers by Brown and others (1982). Based on their relationship, calving rates of $1350 \mathrm{~m} \mathrm{a}^{-1}$ for $50 \mathrm{~m}$ water depth and $810 \mathrm{~m} \mathrm{a}^{-1}$ for $30 \mathrm{~m}$ would be expected. The observed values for Hansbreen are in the range of the calving-rate/ water-depth relation suggested for fresh-water calving glaciers (Funk and Röthlisberger, 1989). On a seasonal timescale the calving rates undergo strong changes from zero calving in winter up to $500 \mathrm{~m} \mathrm{a}^{-1}$ in summer and show no correlation to water depth, which is also known from Columbia Glacier (Sikonia, 1982).

\section{MODELLING THE RETREAT OF 1982-98}

A time-dependent numerical model for the glacier flow of tidewater glaciers (Vieli and others, 2001) is applied to Hansbreen to test the concept of a flotation criterion for calving and to investigate whether the rapid retreat can be a result of buoyancy-induced calving.

\section{Model description}

The numerical model used here to study the retreat of Hansbreen was described and discussed in Vieli and others (2001). It calculates the surface evolution and the twodimensional velocity and stress fields for a longitudinal section of the glacier. The two-dimensional force-balance and mass-conservation equations are solved to compute stress and velocity fields using the finite-element method. Glen's flow law is used in the model with a flow-law exponent $n=$ 3 and a rate factor $A=0.1 \mathrm{bar}^{-3} \mathrm{a}^{-1}$.

\section{Calving}

Calving is implemented in the model by two different schemes. A seasonal calving rate, for which melting at the water-line may be the controlling process, is included in the model by the seasonal calving scheme, in which the calving rate is prescribed according to the observed seasonal pattern.

Additionally, a flotation criterion is included which is described in detail in Vieli and others (2001) and is similar to the criterion suggested by Van der Veen (1996). For each time-step the new terminus is moved to the position where the ice thickness $h$ exceeds the flotation height by the fraction $q=0.15$. The ice mass that is removed corresponds to the mass loss due to calving. Following this method, the calving rate is a result of the computation and is controlled by the ice velocity and the surface-elevation changes.

The calving process is implemented in the model as follows: At each time-step, first the front position is shifted according to the prescribed seasonal calving rate. Then the terminus position is updated according to the modified flotation criterion. Calving is governed by buoyancy whenever a part of the glacier surface in the terminus area is below the 

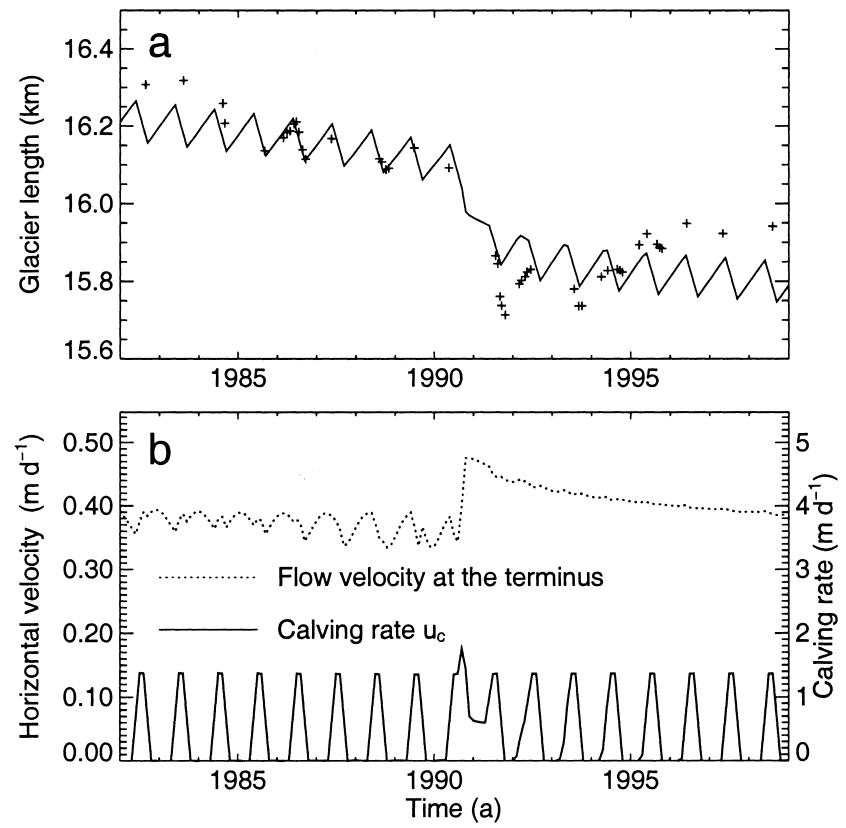

Fig. 6. (a) Modelled (solid line) and observed (crosses) front positions of Hansbreen with time. The time axis is matched to observed front positions. (b) Modelled horizontal surface velocities at the terminus (left scale) and calving rates (right scale) are shown with time.

critical height above buoyancy. With this approach, the model decides whether the prescribed seasonal or the buoyancy-induced calving is the controlling process for calving.

\section{Basal sliding}

A commonly used water-pressure-dependent sliding relation (Bindschadler, 1983) of the form

$$
v_{\mathrm{b}}=k \tau_{\mathrm{b}}^{m} p_{\mathrm{e}}^{-r}
$$

is included in the model, where $v_{\mathrm{b}}$ is the basal velocity, $\tau_{\mathrm{b}}$ the basal shear stress, $k$ is an adjustable empirical positive parameter and $p_{\mathrm{e}}$ the effective pressure. The parameters $m$ and $r$ are set to 1 such that we get a linear sliding relation. Vieli and others (2000) used the same linear relation to explain the flow pattern of Hansbreen and gave a detailed description for the implementation of Equation (1) in the numerical model. The factor $k$ and the effective pressure $p_{\mathrm{e}}$ in Equation (1) are input to the model, and the basal velocity and basal shear traction result from solving the system of field equations and boundary conditions. The effective pressure changes with time and has to be updated for each timestep with the actual ice thickness and basal water pressure.

\section{Model input}

The model calculations were focused on the period 1982-98, with special interest in the 1990/91 season in which the abrupt retreat occurred. The 1936 surface is used as the starting geometry for the model (Fig. 5a).

\section{Sliding parameter and water level}

The sliding parameter $k$ and the englacial water level for the numerical model are not known and are adjusted by minimizing the root-mean-square error between modelled and observed surface flow velocities. Sea level is a lower limit for the englacial water level, but, especially during the melting season, the water level is higher and is assumed to increase linearly with distance to the terminus with a water-level gradient $\alpha$, starting at sea level at the calving front. We additionally assumed that the water level does not exceed $120 \mathrm{~m}$, to take into account in a simple way a decreasing water-level gradient upstream.

The model parameters determined by fitting the modelled to the observed velocities of the mean-flow 99 period are $k=$ $470 \mathrm{~m} \mathrm{a}^{-1}$ and $\alpha=1.6^{\circ}$ (Fig. 5) and are used for modelling the retreat of Hansbreen. For the two slow-flow periods 98 and 99 the same sliding parameter $k$ is found, but $\alpha$ is smaller, which is consistent with the expected lower water pressure. The resulting water level to the optimized $\alpha=1.6^{\circ}$ is $120 \mathrm{~m}$ at the location of the glacier moulin, which is in agreement with the observed water level for this mean-flow 99 period (Fig. 5a).

\section{Input mass-balance function}

There are no mass-balance data available for the period before 1991. A surface-altitude $S$ dependent mass-balance function $b$ averaged over the years 1991-95 is used as input for the model which is given by

$$
b=a_{1} S+a_{0},
$$

with the coefficients $a_{1}=0.0066 \mathrm{a}^{-1}$ and $a_{0}=-2.20 \mathrm{~m} \mathrm{a}^{-1}$. This mass-balance function includes surface accumulation and ablation without calving. The mass-balance function $b$ may not be representative for the entire period from 1936 until today, but its mean average net balance is consistent with the value estimated from the glacier volume change between 1936 and 1990. Because of the uncertainty in the mass-balance input, additional model runs were performed with a shift of the mass-balance function by $\pm 0.2 \mathrm{~m}$ w.e. $\mathrm{a}^{-1}$.

\section{Calving rate}

Beside the flotation criterion for calving, a seasonal cycle of calving rate $u_{\mathrm{c}}$ is prescribed according to observations. We assumed no calving for the 8 month period from the beginning of October to the beginning of June, and for the four summer months (June-October) we used the observed 1986 value of $1.37 \mathrm{~m} \mathrm{~d}^{-1}$. The resulting mean annual calving rate amounts to $0.45 \mathrm{~m} \mathrm{~d}^{-1}$. To show the sensitivity of the model results to the prescribed calving rates, additional model runs with different summer calving rates of 1.28 and $1.46 \mathrm{~m} \mathrm{~d}^{-1}$ were performed.

\section{MODEL RESULTS AND DISGUSSION}

The modelled front position shows a general slow retreat with a superimposed annual cycle (Fig. 6). A jump in the modelled retreat of about $220 \mathrm{~m}$ occurs in year 47 after the model start which takes place over the region where the depression in the glacier bed is located (Figs 6 and 7). The glacier thins continuously with time due to the imposed negative mass balance. In the frontal region, where the basal topography at the terminus slopes up in flow direction, the thinning is found to be accelerated.

The modelled retreat of the period 1982-98 is not expected to be accurate in time, because the calculated mean retreat rate mainly depends on the assumptions made for the mass-balance history and the annual prescribed calving rate. The model calculations start in 1936 in order to have a long enough spin-up period for realistic initial conditions for the jump in 1990 in which we are interested. The position and shape of the jump in retreat is very robust with regard to different mass-balance inputs and prescribed calving rates for the spin-up, as discussed below. To obtain the 


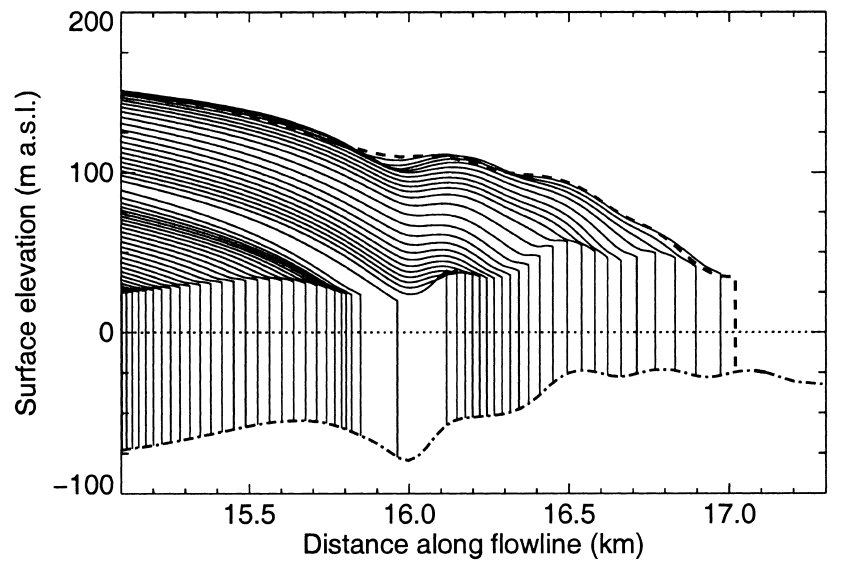

Fig. 7. Modelled evolution of the glacier surface with time along the flowline. The time interval between two surface profiles is 2 years. The starting geometry of 1936 is indicated by the dashed line. The dashed-dotted line indicates the glacier bed topography along the flowline.

modelled abrupt length change at the true time (1990/91), the model time is shifted accordingly (Fig. 6).

The seasonal variations of the front position, well reproduced by the model calculations (Fig. 6a), are a direct consequence of the prescribed seasonal calving rate, estimated from observations. The modelled abrupt retreat is due to the flotation criterion, and the position where it takes place corresponds well to the observations. Additional model runs were performed with different values for the prescribed seasonal calving rate, a different input mass balance or a lower water-level inclination $\alpha$. The location of the abrupt retreat remains the same and is fixed to the position of the depression in the basal topography, although the model time of these jumps differs.

Treating calving by a flotation criterion, the resulting retreat and calving rate are a direct consequence of the surface evolution near the terminus and therefore expected to be affected by basal topography. Before the jump in retreat takes place, the surface elevation at the calving front is always above the critical height above flotation, and the prescribed mass balance and seasonal pattern of the calving rate control the retreat. With retreat and thinning of the glacier, a slight depression develops at the surface above the trough in the glacier bed (Fig. 7). The glacier surface thins below the critical height above buoyancy, and according to the flotation criterion, all the ice in front is removed. Instead of the prescribed seasonal calving, the buoyancyinduced calving now becomes the governing process and the retreat is mainly controlled by surface lowering in the terminus region. When the terminus reaches the region of a downslope bed in the flow direction with shallow water, the surface exceeds the critical height, and the prescribed seasonal calving again becomes the controlling process.

The model calculations show how the surface of Hansbreen during retreat evolves with time in the region of the depression in the glacier bed (Fig. 7). The resulting rapid retreat and high calving rates are a direct consequence of applying a flotation criterion to this evolving surface, and therefore a result of the surface dynamics. The rapid retreat well reproduced by the modelling therefore supports the idea derived from the observations that the rapid retreat and the high calving rates are a result of buoyancy-induced calving in the region of a depression in the glacier bed.

For the model calculations the prescribed seasonal calving rate and the input mass-balance function are kept constant with time, corresponding to constant climatic conditions. The modelled rapid retreat, as a response to this external forcing, clearly shows that front-position changes of tidewater glaciers do not directly reflect the climatic signal and are strongly affected by basal topography.

The proposed two relevant processes for calving do not distinguish between fresh water and tidewater, so there is no fundamental restriction on applying our model to fresh-water glaciers. The magnitude of the calving rate may be affected by the difference of buoyancy in fresh water and tidewater or by the different melt rates at the water-line, due to differences in salinity and wave activity.

\section{GONGLUSIONS AND PROSPEGTS}

The observed seasonal changes of the front position of Hansbreen are mainly due to variations of the calving rate. The main calving period occurs during summer and corresponds to the period of surface melting and highest sea-water temperatures in the fjord. In winter the calving rate is close to zero, resulting in an advance corresponding to the ice flow at the calving front. The commonly observed calving process and notch at the water-line and the observed seasonal pattern of calving indicate that, during periods of slow front-position changes, melting at the water-line may play an important role as a triggering mechanism for calving.

The observed rapid retreat of the front position of Hansbreen in 1990/91 is found to be related to a depression in the glacier bed in the terminus region. The process of buoyancyinduced calving is suggested to govern the abrupt retreat, and the general thinning of Hansbreen due to a long-term massbalance deficit is expected to be the triggering process. This supports the flotation model of Van der Veen (1996) proposed for the rapid retreat of Columbia Glacier.

The observed calving rates and corresponding terminus water depths for Hansbreen's slow-retreat period result in a calving-rate to water-depth relationship which is similar to the function inferred from observations of fresh-water calving glaciers (Funk and Röthlisberger, 1989). Thus, the Hansbreen data call into question the existence of a different relationship for fresh-water and tidewater glaciers.

The model calculations show that by treating calving with a flotation criterion we are able to reproduce the observed rapid retreat of Hansbreen. This supports the idea that the abrupt retreat and enhanced calving rate is a result of the strong influence of bed topography on surface evolution, and therefore primarily a result of glacier dynamics, and not vice versa. The successfully modelled rapid retreat supports the use of a flotation criterion to model the dynamics of tidewater glaciers. Although the flotation criterion used leads to a reasonable dynamics of tidewater glaciers, the physical mechanism of calving behind this criterion is not addressed in this study and needs to be further investigated.

Rapid retreats through depressions in the glacier bed were observed on several tidewater glaciers, but these studies were mostly focused on large, fast-flowing glaciers with calving rates and frontal velocities in the order of $1 \mathrm{~km} \mathrm{a}^{-1}$. This study of Hansbreen shows that the effect of basal topography on the dynamics of small, slowly flowing tidewater glaciers is similar.

The observations and model calculations of Hansbreen support the idea that rapid unstable retreats of grounded 
calving glaciers in fresh water or tidewater are mainly related to depressions in the glacier bed in the terminus region and are only to a minor degree a direct response to climate change. Because of the sensitivity of length changes of grounded calving glaciers to basal topography, their future behaviour with respect to climate change is difficult to predict and requires an accurate knowledge of the glacier bed.

\section{AGKNOWLEDGEMENTS}

We thank H. Blatter, M. Funk and K. A. Echelmeyer for reading the manuscript and helping to improve it substantially. We further appreciate the valuable comments of R. Greve, A. Ohmura and two anonymous reviewers. The field photogrammetric surveys of the Hansbreen front were conducted and sponsored by the University of Silesia and the Institute of Geophysics, Polish Academy of Sciences. The field observations of J. Jania and L. Kolondra were conducted, in part, as a contribution to the European Community "ICEMASS" project. The Geophysical Institute of the Polish Academy of Sciences provided the infrastructure of the Polish Polar Station in Hornsund during the field investigations. We also thank P. Vieser, who was responsible for the GPS survey in summer 1999. The work was supported by ETH grant No. 0-20-400-97, Zürich, Switzerland.

\section{REFERENGES}

Baranowski, S. 1977. The subpolar glaciers of Spitsbergen seen against the climate of this region. Acta Univ. Wratislav. 410.

Bindschadler, R. 1983. The importance of pressurized subglacial water in separation and sliding at the glacier bed. F. Glaciol., 29(101), 3-19.

Boulton, G. S. and R. C. A. Hindmarsh. 1987. Sediment deformation beneath glaciers: rheology and geological consequences. 7. Geophys. Res., 92(B9), 9059-9082.

Brown, C. S., M. F. Meier and A. Post. 1982. Calving speed of Alaska tidewater glaciers, with application to Columbia Glacier. U.S. Geol. Surv. Prof. Pap. 1258-C.

El-Tahan, M., S. Venkatesh and H. El-Tahan. 1987. Validation and quantitative assessment of the deterioration mechanisms of arctic icebergs. F. Offshore Mech. Arct. Eng., 109(1), 102-108.

Funk, M. and H. Röthlisberger. 1989. Forecasting the effects of a planned reservoir which will partially flood the tongue of Unteraargletscher in Switzerland. Ann. Glaciol., 13, 76-81.

Giżejewski, J. 1997. Bottom morphology of the Hans Glacier forefield (Hornsund, south-west Spitsbergen, Svalbard). Preliminary report. In Głowacki, P., ed. Polish Polar Studies, 24th Polar Symposium. Warszawa, Polish Academy of Sciences. Institute of Geophysics, 63-69.

Glazovskiy, A. F., L. Kolondra, M.Yu. Moskalevskiy and Ya. Yaniya. 1992. Research into the Hansbreen, a tidewater glacier in Spitsbergen. Polar Geogr. Geol., 16(3), 243-252.

Haeberli, W., M. Hoelzle and S. Suter, eds. 1996. Glacier Mass Balance Bulletin. Bulletin No. 4 (1994-1995). Zürich, IAHS(ICSI), World Glacier Monitoring Service; Nairobi, UNEP; Paris, UNESCO.

Hanson, B. and R. LeB. Hooke. 2000. Glacier calving: a numerical model of forces in the calving-speed/water-depth relation. f. Glaciol., 46(153), 188-196.

Hunter, L. E. and R. D. Powell. 1998. Ice foot development at temperate tidewater margins in Alaska. Geophys. Res. Lett., 25(11), 1923-1926.
Jania, J. 1988. Dynamiczne procesy glacjalne na poludniowym Spitsbergenie (w świetle badan fotointerpretacyjnych i fotogrametrycznych) [Dynamic glacial processes in south Spitsbergen (in the light of photointerpretation and photogrammetric research) ]. Katowice, Uniwersytet Ślasski. (Prace Naukowe Uniwersytetu Śląskiego w Katowicach 955.)

Jania, J. 1994. Field investigations during the glaciological expeditions to Spitsbergen in the period 1992-1994: interim report. Katowice, University of Silesia. Faculty of Earth Sciences, Department of Geomorphology.

Jania, J. and M. Kaczmarska. 1997. Hans Glacier - a tidewater glacier in southern Spitzbergen: summary of some results. Byrd Polar Res. Cent. Rep. $15,95-104$

Jania, J. and L. Kolondra. 1982. Field investigations performed during the glaciological Spitsbergen expedition in the summer of 1982: interim report. Sosnowiec, Poland, Uniwersytetu Śląskiego. Instytut Geografii.

Kirkbride, M. P. and C. R. Warren. 1997. Calving processes at a grounded ice cliff. Ann. Glaciol., 24, 116-121.

Kosiba, A. 1960. Some results of glaciological investigations in SW-Spitsbergen carried out during the Polish I.G.Y. Spitsbergen Expeditions in 1957, 1958 and 1959. Wroclaw, Zeszyty Naukowe Universytetu Wroclawskiego. (Serie B 4.)

Meier, M. F. and A. Post. 1987. Fast tidewater glaciers. 7. Geophys. Res., 92(B9), 9051-9058.

Moore, J. C. and 8 others. 1999. High-resolution hydrothermal structure of Hansbreen, Spitsbergen, mapped by ground-penetrating radar. f. Glaciol., $45(151), 524-532$.

Moskal, W. 1987. Charakterystyka hydrologiczna zatoki białego niedźwidzia (Spitzbergen) [Hydrological characteristics of the Isbjornhamna (Spitsbergen)]. Gdansk, Universytetu Gdanskiego. Instytut Oceanografii. (Technical Report.)

Naruse, R. and P. Skvarca. 2000. Dynamic features of thinning and retreating Glaciar Upsala, a lacustrine calving glacier in southern Patagonia. Arct. Antarct. Alp. Res., 32(4), 485-491.

Neshyba, S. and E. G. Josberger. 1980. On the estimation of Antarctic iceberg melt rate. 7. Phys. Oceanogr., 10(10), 1681-1685.

Powell, R. D. 1988. Processes and facies of temperate and sub-polar glaciers with tidewater fronts. Boulder, CO, Geological Society of America. (Geological Society of America Short Course Notes.)

Robe, R. Q., D. C. Maier and R. C. Kollmeyer. 1977. Iceberg deterioration. Nature, 267(5611), 505-506.

Sikonia, W. G. 1982. Finite-element glacier dynamics model applied to Columbia Glacier, Alaska. U.S. Geol. Surv. Prof. Pap. 258-B.

Swerpel, S. 1982. Hydrological investigations of the coastal waters in the Hornsund fiord in the summer of 1975. Wratislav, Acta Universitatis Wratislaviensis. (Interim Report 525.)

Van der Veen, C. J. 1996. Tidewater calving. F. Glaciol., 42(141), 375-385.

Van derVeen, C. J. 1998. Fracture mechanics approach to penetration of bottom crevasses on glaciers. Cold Reg. Sci. Technol., 27(3), 213-223.

Venteris, E. R. 1999. Rapid tidewater glacier retreat: a comparison between Columbia Glacier, Alaska and Patagonian calving glaciers. Global Planet. Change, 22(1-4), 131-138.

Vieli, A., M. Funk and H. Blatter. 2000. Tidewater glaciers: frontal flow acceleration and basal sliding. Ann. Glaciol., 31, 217-221.

Vieli, A., M. Funk and H. Blatter. 2001. Flow dynamics of tidewater glaciers: a numerical modelling approach. f. Glaciol., 47(159), 595-606.

Warren, C. R. 1993. Rapid recent fluctuations of the calving San Rafael Glacier, Chilean Patagonia: climatic or non-climatic? Geogr. Ann., 75A(3), 111-125.

Warren, C. R. 1999. Calving speed in freshwater at Glaciar Ameghino, Patagonia. Z. Gletscherkd. Glazialgeol., 35(1), 21-34.

Warren, C. and M. Aniya. 1999. The calving glaciers of southern South America. Global Planet. Change, 22(1-4), 59-77.

White, F. M., M. L. Spaulding and L. Gominho. 1980. Theoretical estimates of the various mechanisms involved in iceberg deterioration in the open ocean environment. Washington, DC, U.S. Coast Guard. Research and Development Center. (Report CG-D-62-80 81-20571.) 